An International Multidisciplinary Journal, Ethiopia

Vol. 7 (3), Serial No. 30, July, 2013:217-231

ISSN 1994-9057 (Print)

ISSN 2070--0083 (Online)

DOI: http://dx.doi.org/10.4314/afrrev.v7i3.16

\title{
Jesus: Born Poor or Rich?
}

Osai, O. Jason - Institute of Foundation Studies (IFS), Rivers State University of Science and Technology, P. M. B. 5080, Port Harcourt, Nigeria

E-mail: jasonosai1@yahoo.com

Phone: +2348037851138

\begin{abstract}
Over the centuries in Christendom, the clergy has consistently drummed it into the ears and consciousness of the laity that Jesus was born poor; this has been phenomenal and the adherents of Christian religion have accepted and imbibed it without question. Drawing from anecdotes and accounts that contain essential tell-tales of the circumstance of the birth of Jesus, this effort subjects the accounts and assertions to critical analysis to determine the veracity or otherwise of this perception. The paper therefore, looks at the profession of carpentry within the context of time and place, the family background of Virgin Mary with special reference to the socioeconomic status of her parents, the fundamental rules of the Yenta function, the circumstances surrounding the birth of Jesus in a manger, the financial implication of the ability to escape to Egypt on short notice and, finally, the whereabouts of Jesus during the eighteen years that are conspicuously missing in the literature of Judeo-Christian theology. The paper concludes that, like tailoring, smith, masonry etc. carpentry was part of a guild that only those with means practiced in Judaea of that epoch and, therefore,
\end{abstract}


Joseph was not poor; that Joachim, the maternal grandfather of Jesus, was a wealthy descendant of the royal house of David; that Joseph had the means to take a room in an inn but could not as a result of the fact that there were no vacancies hence he took his wife to the manger; that Jesus journeyed far and wide internationally and had privileged education and, in view of the foregoing, the paper posits that Joseph Carpenter was a wealthy professional and that his son, Jesus of Nazareth, was, therefore, born rich.

\section{Introduction}

In church after church, worldwide, the clergy bombards the congregations with priestly pronouncements that generate reflexive responses that are devoid of deep thought on the part of the frenzied faithful; that would not be necessary: after all, the man of God is inspired by God and so he knows and speaks the mind of God. In that unquestioning state of mind, the congregation reflexively and rapturously thunders "Amen" when the man of God pronounces: "Jesus was born poor that I might be rich." This, the congregation does believing every word of that pronouncement; after all, the pronouncement emanated from the pulpit; it is, therefore, sacrosanct. While this is generally common in all the churches, the phenomenon pervades predominantly in Pentecostalism.

Time, place and, therefore, peculiar circumstance are veritable variables that have the potency of impacting on people, things and concepts in such a manner that render them unrecognizable when perceived and reviewed within the context of a different epoch, locale and, therefore, the original context. Jesus and his brand of message of salvation have been subjected to various analyses and interpretations reflecting the theological or philosophical perspectives of the various analysts. In this effort, we shall not bother with the teachings of Jesus; neither shall we delve into the issue of his deification. Our primary interest in this fundamentally intellectual enterprise is to subject the socioeconomic background of Joachim and Anna (the parents of the Virgin Mary) and Joseph the carpenter to critical analysis within the context and purview of perceived socioeconomic setting in which Jesus was born and raised; the objective is to determine the veracity or otherwise of the persistent priestly pronouncement that Jesus was born poor. Was the concept of "born poor" a Divine-designed symbolism or was it a true reflection of the socioeconomic circumstance of Joseph and, therefore, the birth of Jesus? What is being hidden in the biblical amnesia of the eighteen years spanning age twelve when he chased money changers and traders from the synagogue 
and thirty when he commenced His ministry? Was he born with all the knowledge that crystallized in his ministry or was he exposed to education? If the answer is in the affirmative, then where? These are the questions that his paper sets forth to lay to rest.

In this pursuit, the literature of Judeo-Christian theology, extra-biblical texts and the scriptures of other religions were searched and studied in accordance with Jesus' counsel and encouragement thus "seek and ye shall find, ask and it shall be given you and knock and it shall be opened." (Matthew, 7:7; Luke, $11: 9-13 ; 18: 1-8$. John, 15:7) "For everyone that asketh receiveth; and he that seekest findeth and to him that knocketh it shall be opened." (Matthew, 7:8; Jer, 29:12)

\section{Jesus: Born Poor or Rich?}

Fundamentally, conflict is pervasive in human society. Interestingly, its manifestation cuts across the psychological, the political, the social, the anthropological dimensions and other spheres of human existence. In its ramification, conflict starts at the individual level with the possibility of extension to the society at large. Of all sources of conflict in humanity, religion stands as the one that attracts the most intense reaction with people, generally, being fanatical and, consequently, ready to pay the supreme price in the name of the essence of their creed; in other words, the conflictgenerating capacity of religion in humanity is phenomenal. Resultantly, we are entering into this enterprise with great caution (not fear though) to keep our analysis within the context and confines of the academic endeavor, which it is. We shall, therefore, take an episodic view of our inquiry beginning from the beginning and on to the end: 1) the profession of carpentry with special reference to its placement in Judaea of that era vis-à-vis the current global perception of the profession, 2) the maternal grand parentage of Jesus, 3) the tacit rule of the Yenta function, 4) circumstances surrounding the birth in a manger, 5) the socioeconomic significance of the ass as a means of transportation, 6) the unplanned escape to Egypt at the potent threat of Herod's intention to hill the newborn king and 7) the missing years, which have been a source of curiosity to humanity for ages.

\section{The Carpentry Profession in Context}

The names Smith, Goldsmith, Taylor, Tyler, Mason, Glazer, Carpenter, Schumacher, Fowler, Wells, Sawyer, Archer, Hunter, Miller, Tanner etc, which some people still bear till date as their surnames, are names that 
proudly proclaim the profession of their forebears or family. These trades, which, as indicated above, include carpentry, were old guilds with closely guarded and guided conditionalities before admission; only people of substantial means were admitted into them including apprenticeship. Again, these professions required certain implements of labor that only those with the means at the time (the wealthy) could afford. Crane (1963:29-30) quotes Joseph, who is said to have been 33 years old when he contracted the marriage with the thirteen year-old Virgin Mary, as saying thus: "I must go to mind my trade of building" and furthers that "Joseph [was] building houses abroad." At age 33 and building houses abroad indicate that he was a very mature professional who had mastered his trade to the point he had clientele overseas. Again, the statement "Joseph [was] building houses abroad" indicates that Joseph was not the table and kitchen chair carpenter of our contemporary perception of the trade; rather, he was a builder to whom we can safely ascribe with undertaking contractual agreements to build "houses abroad."

Obviously, carpenters were the first set of builders before masons, glazers etc entered the industry of home building. Therefore, to assess Joseph, to whom we shall now add the surname Carpenter, as a poor man is to place his profession and the consequent socioeconomic status within the context of current society instead of within the context of the time (more than two thousand years ago) and place (Judaea) in which he lived. Perhaps a more appropriate classification of Joseph within the contemporary context of his profession would be a combination of an architect and construction engineer with the capacity of delivering housing projects on contractual basis.

\section{The Parentage of the Virgin Mary}

As will be elaborated upon presently under the subtitle "The Tacit Rule of the Yenta Function," a ground rule of the yenta (matchmaking) function is due consideration for minimal socioeconomic disparity between the two families whose children are being matched. Having internalized this state of mind, we are informed that:

Mary sprung from the royal race and family of David, was born in the city of Nazareth and educated at Jerusalem...her father's name was Joachim and her mother's Anna. [Her parents] divided all their substance into three parts: one of which they devoted to the temple and officers of the temple; another they distributed to 
strangers and people in poor circumstance (emphasis mine); and the third they reserved for themselves and the uses of their family. (Crane, 1963:17/8)

If we set aside the argument of having "sprung from the royal race and family" that may not necessarily imply or guarantee wealth, we note that the Virgin Mary "was born in the city of Nazareth and educated at Jerusalem." Implicit in this account is that she was sent from Nazareth, the city of her birth, to Jerusalem for education; even by the standards of Judaea of that epoch, the education of the boy child belonged amongst the rich; now, for a family to send its girl child to school not in the home city but in faraway Jerusalem, which was the regional center of learning and a comparatively expensive city, is a clear indication of not only wealth but consciousness of the invaluable essence of education. It can be surmised that the parents of the Virgin Mary were not only rich but were also educated or sufficiently exposed, in the least. We also note the tell-tale essence of Joachim and Anna distributing the second of the tripartite division of their substance "to strangers and people in poor circumstance." This clearly shows that Joachim and Anna were not people in poor circumstance; it is surmised, therefore, that they were rich.

The above finds correlation with the fact that Elizabeth (Mary's senior cousin) was married to Zachariah, a priest. We note that during that epoch, priesthood was (as it still is) a noble profession that attracted favored contemplation devoid of pecuniary considerations; there may not have been direct economic gains in the profession, however, priests never lacked anything for their upkeep and those of their family as the followers of the creed fell over each other to provide for the messengers of God in expectation of the blessings of God in return. Like Joachim and Anna, devout Jews devoted "a third of ... all their substance to the temple and officers of the temple." An agglomeration of a third of all the substance of followers in a particular parish certainly would add up to a handsome sum that would make the warehouse of the Lord a place of utmost abundance; Zachariah had access to comfort. Rowe (2006:24) informs that in the Jewish world of Jesus' era, about ninety percent of the population of one to two million were "people of the land"-cultivators of the land; the Pharisees, most of whom lived in Judaea or near Jerusalem, were a small part and constituted about six thousand of the population; they observed and taught the law in all its details. The third group, the Sadducees, constituted an even smaller percentage of the population and they were "members of wealthy aristocratic families from 
Jerusalem many of [whom] were priests." Subjected to syllogistic reasoning, we can hypothesize that since priesthood was a profession for the wealthy Sadducees and Joachim was a priest that he was, most likely, a Sadducee; however, Sadducee or not, one point is clear: the father of the Virgin Mary was a wealthy person. From the foregoing, it is abundantly clear that the genealogical string that connected Jesus to the royal race and house of David came from both parents.

Today, true priesthood is still noble and the palpable pecuniary potentials have added to the perceived dignity of the profession; again, the degree to which the flock falls over each other to provide for the priests is very enormous.

\section{The Tacit Rule of the Yenta Function}

Marriage is the foundation and beginning of the family, which is known as the basic institution of socialization. (White, 1977) Generally, great care is taken in choosing a partner in what is seen as a journey of life together. Beyond ascertaining that the character of the intended spouse is good and the groom is mature enough to cope with the pressure of marriage, a major factor that is considered is the socioeconomic background of the families of the intended couple. Here, the aphorism: "there is no romance without finance" presents a bowl full of food for thought; in both cases, the function and services of the matchmaker (Yenta in the Jewish tradition) becomes very important.

We note that in that era, matchmaking was, generally, informed, if not strongly influenced, by socioeconomic considerations; even today, such considerations have not seized to be a major factor. As a matter of fact, it is easier to find a bride from a poor background being united in marriage with a groom from a wealthy socioeconomic background than to see a bride from a wealthy background being matched with a poor groom. Therefore, it is offered that Mary's father, who, as we have demonstrated, was wealthy, gave his daughter to the son of a professional rather than the son of a poor man.

\section{The Socioeconomic Significance of the Ass}

Did the pregnant Virgin Mary embark on the journey from Nazareth to Bethlehem on foot? That would be very unlikely as it is unfeasible given the fact that she was due. While no account was given in the Bible regarding the means of travel, Crane (1963:32) offers that Joseph "saddled the ass and put [Mary] upon it, and Joseph and Simon followed after her." Did Joseph and 
Simon follow on foot or did they have their asses? This question is not answered by the anecdote; however, what is clear is that Joseph had at least one ass. We note that a Hollywood account presents Joseph Carpenter and his wife travelling not with one or two asses but with three mules: one, carrying the pregnant Mary and the other two carrying Joseph and their baggage, respectively. Granted that this account is subject to disputation, it would be commonsensical to say that the Virgin Mary wife of a professional did not walk from Nazareth to Bethlehem. While three asses may be a product of the exaggeration that characterize the cinematographic productions of Hollywood and all the other "Woods" (Bolly, Nolly etc), travelling the distance of three miles without one in the particular circumstance of a heavily pregnant wife whose due date was at hand, would be very unlikely. That Simon joined the couple on the journey making them three lends some degree of credence to the Hollywood version of three asses. If this hypothesis is accepted, the mere fact that Joseph could afford three asses or even one for the journey clearly spells out his privileged position in the socioeconomic strata of Judaea of that era. Placing the ass in context, it is offered that asses of that epoch can be equated with sports utility vehicles (SUVs) of today while horse-driven carriages or chariots of that era would be equivalent to stretch limousines or private jet of today. Joseph and company travelled in either the equivalent of one vehicle or a three-vehicle motorcade; therefore, he was not a poor man; rather, he was a wealthy professional. We note that when Jesus wanted to ride into the city of Jerusalem (the Triumphant Entry), he requested that the ass of a certain rich man be brought.

\section{The Birth in a Manger}

Biblical accounts indicate that when Joseph arrived at Bethlehem for the census, he went from one inn to another in search for room to lodge with his pregnant wife but was not able to find one on account of the fact that all the inns were fully booked; this phenomenon is common till date: when major events take place in cities, the hospitality industry is usually overstretched and the hotels are generally fully booked except for those who made reservations. This therefore means that the birth of Jesus in a manger where animals are kept was circumstantial: it was predicated on the non-availability of accommodation at the inns rather than the issue of non-affordability or poverty. Joseph Carpenter had enough money to pay for a space in an inn and searched extensively for one but could not find so, out of frustration and shire necessity or Divine design, he resorted to a manger. 
In a reaction that clearly casts doubt to the veracity of the "born in the manger" anecdote, the English poet, Sir John Betjeman (1906-84) poetically asks:

Is it true, is it true?

This most tremendous tale of all

Seen in a stained-glass window's hue

A Baby in an ox's stall?

"A stained-glass window's hue" captures the degree of doubt in the mind of Betjeman who may have many more sharing those thoughts; this is not the focus of the paper. Standing outside a building with windows made of stained-glass, it is usually impossible to see what is inside the house in its true (hue) colors; the best that is achievable under the circumstance is a silhouette that gives away nothing but the outline. The fact remains that the plausibility of not finding space in an inn at a time of such governmentordered exercise that required mass influx of people to the town is not in doubt; it is a very common phenomenon even by today's standard when the tourism industry has exploded considerably.

\section{Impromptu Escape to Egypt}

Following the threat by King Herod to kill all new-born male children, Joseph took his wife and newborn baby and escaped to Egypt. That Joseph Carpenter was able to take his family on that journey is indicative of some means as such journeys cost considerably then as they still do, today. We note that during that epoch there were only two ways of journeying from Palestine to Egypt: 1) through slavery or indentured servitude in which case the slave owner or master foot the bill; (this was how Joseph son of Jacob travelled to Egypt); or 2) self sponsorship, which was the prerogative of people of means who, generally, went to purchase essential commodities as the other sons of Jacob did. Corollary to this is the fact that Joseph Carpenter was able to embark on this trip on short notice. We are told that:

And when [the wise men from the East] were departed, an angel of the Lord appeared to Joseph in the dream saying 'arise and take the young child and his mother and flee to Egypt and be thou there until I bring you word for Herod will seek the young child to destroy him.' When he rose, he took the young child and his mother by night and 
departed into Egypt and was there until the death of Herod. (Matthew 2:13-5)

What the above signifies is that Joseph had more than enough money on him when he took his pregnant wife to Bethlehem for the census; he had enough money that enabled him to embark on that unplanned expensive trip to Egypt. Again, that Joseph stayed in Egypt "until the death of Herod" emphasizes the extent of Joseph's liquidity. Even by today's standards, such excess liquidity is the prerogative of people of means; this is without prejudice to the effects of the plastic economy, which, to a great extent, is not available to all, especially carpenters of today. If, however, we assume that Joseph did not have that much money to sustain him and his family for long in Egypt, it means that he had access to some money while there and that could only have come from either his personal savings, family, which includes his wealthy father-in-law, or from practicing his profession while in Egypt; after all, we are told that he was "building houses abroad" (Crane, 1963:30) and Egypt was a next-door neighbor and a favorite destination of refuge for Israelites. Unfortunately, the Bible did not indicate how long it took till Herod died.

\section{The Missing Years}

Beyond the issue of the deification of Jesus, which extra-biblical literature tells us was effected through a vote by the Nicene Council in 325AD, an issue that has attracted so much controversy amongst the Christian faithful and scholars is the eighteen missing years in the account of the life of Jesus. From the account of St. Luke, we note that from the age of twelve when Jesus rebuked those who turned the House of God into a den of thieves and when he emerged and was baptized by John the Baptist, there are eighteen years. It is very worrisome that this period of Biblical selective amnesia covered the most active and, consequently, adventurous years of any one's life; this period has been a source of curiosity for those who have had the courage to ask pertinent questions; questions regarding which the clergy has remained tight-lipped; and, ironically, the muted quest for answers has turned into thunderous silence.

Obviously, the gospels differ in their degree of taciturnity in regard the missing years. For instance, on the return journey from Egypt following the death of Herod, Matthew (2:20/21) tells us that on being commanded by "an angel of the Lord" to "arise and take the young child and his mother and go unto the land of Israel...[Joseph] arose, and took the young child and his 
mother and came into the land of Israel." Beyond this, Matthew chronicled no other account of Jesus until he came "from Galilee to Jordan unto John [the Baptist] to the baptized." (Matthew, 3:13) We can surmise therefore that the period of silence in Matthew may be up to twenty-five years. Far greater than the taciturnity of Matthew is that of Mark, who neither gave an account of the birth of Jesus nor any information on him until "it came to pass in those days that Jesus came from Nazareth of Galilee and was baptized of John in Jordan." (Mark, 1:9) Here we are dealing with silence over the entirety of Jesus' life until he was baptized at thirty as generally conjectured.

Luke offers far more details on the childhood than Matthew and Mark; from Luke we learn that when Jesus was twelve, Joseph, in conformity with Jewish tradition, took his family to Jerusalem for the annual feast of Passover. After the feast, Jesus strayed away from his parents who could not find him till after three days; eventually, they found him "in the temple, sitting in the midst of the doctors, both hearing them and asking them questions... and all that heard him were astonished at his understanding and answers." (Luke, 2:46/47) No further account of the whereabouts of Jesus was given until he was baptized by John the Baptist. (Luke, 3:21) In the account of St. John, the first sighting of Jesus was by John the Baptist who exclaimed thus: "behold the Lamb of God, which taketh away the sin of the world;" (John, 1:29) no account whatsoever was given about his birth, childhood, teenage etc.

If we may offer a summary of the account of the missing years as presented by the synoptic gospels, we note that Luke gives more detailed account of the childhood of Jesus than any of the other gospels; at least its account limited the missing years to eighteen. While Matthew gave an account of the birth, brief sojourn in Egypt and return, which mentioned Jesus at the stage of "young child," Mark and John gave no account whatsoever of his birth and childhood. So for Mark and John the period of silence is thirty years; while, as conjectured earlier, that of Mathew is twenty-five years. It means, therefore, that only Luke that gives an account of the young Jesus up to the age of twelve years; therefore, we can, without fear of contradiction, assert that St. Luke is the author and authority of the childhood of Jesus.

Still on the missing years, we note that it was only in the account by Matthew that Herod threatened to kill Jesus and the family made impromptu trip to Egypt and returned only after the death of Herod. So in all the gospels, the 
inference is that Jesus spent his childhood, teenage and twenties in Galilee. Differing from this, Prophet (1986:8) offers that:

In India, Kashmir and Tibet, there is a long-standing tradition that Jesus was in India during his teens and twenties. An ancient Tibetan manuscript...says that Jesus went with a caravan of merchants along the Silk Road to India, where he studied Hinduism and Buddhism, came into conflict with Hindu and Zoroastrian priests and was revered by the people as Saint Issa.

The ancient manuscript discovered in 1887 by Russian writer Nicola Notovitch and those discovered by Swami Abhedananda, a Hindu teacher in 1922 and Nicholas Roerich, a Russian anthropologist in 1925, though discovered in various countries, gave the same account "concerning Jesus' activities in the East; these accounts came from India, China, Egypt and Arabia." (Notovitch) According to the chronicles of Himis manuscript:

At the age of thirteen [Jesus] set out toward Sind (a region in present-day southeast of Pakistan in the lower Indus River Valley) with the object of perfecting himself in the Divine Word and of studying the laws of the great Buddha...his spiritual power was already apparent for his fame spread throughout northern Sind. He went to Juggernaut, where the white priests of Brahma made him a joyous welcome. From these Hindu priests he learned to reach and understand the Veda, the ancient scriptures of the East and to teach them to the people. He also learned to work miracles to cure by aid of prayer and to drive out evil spirits from the bodies of men. Jesus spent six years between ages fourteen and twenty travelling to Juggernaut, Rajagriha, Benares and other holy cities. He became embroiled in controversy when he insisted on teaching the scriptures to the lower castes; the priests decided to kill him. Jesus was warned and he fled into the foothills of the Himalayas to the birthplace of Gautama Buddha; he spent the next six years in Nepal [where] he mastered the Pali language and became a perfect expositor of the sacred writings of Buddhism. Sometime between the ages of twenty-seven and twenty-nine, he left the Himalayas and journeyed west, preaching along the way.

The Silk Road constituted a network of medieval international road linkages that connected the countries of what we now know as the Middle East and the Far East; doubtlessly, such linkages extended beyond that as peoples and merchants of the world reached out in trade relationships, proselytization, territorial expansionism and what could be considered as the precursor of the 
relatively new concept of imperialism. It can be naturally surmised that the three wise men from the East came to Bethlehem through this route; and it was through this trade route that Jesus returned to the East for the education, experiential learning and works as enunciated above. The cost of the sojourn in the East, as stated above, and Egypt during the eighteen missing years certainly was not within the reach of the son of a pauper; such exposure to education in a foreign land was and still is only within the reach of the privileged - the upper echelon of society. Even by contemporary standards, it is only the children of people of means or those who have government scholarship that have access to such privilege.

\section{Analysis}

To what extent does the "born poor" perception affect the adherents of the Christian faith? What purpose does it serve in the process of proselytization, the search for salvation or self-transcendence? It is opined that the theory panders to the psychological needs of the poor, which though they preponderate in the Third World are also abundant in the developed West. The assumption is that being poor becomes a point of contact that lends the person and, consequently, preaching of Jesus, the desired degree of acceptability amongst that segment of human society that is more populous in every economy; here, the purpose of proselytization is abundantly served. This is perhaps responsible for the fact that in the face of dwindling church attendance and the resultant ever-increasing empty churches in the West, especially in Europe, the Third World is witnessing meteoric rise in converts especially with the new wave of Pentecostalism.

Is church going or the Christian faith for the poor? Certainly not! Granted that Jesus said "go thy way, sell whatsoever thou hast, and give to the poor, and thou shalt have treasure in heaven and come take up the cross and follow me" (Mark, 10:21) and, given the reaction of the rich young man in that encounter, Jesus added thus: "how hardly shall they that have riches enter into the kingdom of God...it is easier for a camel to pass through the eye of the needle than for a rich man to enter into the kingdom of God," (Mark, 10:23/25) the essence of His preaching, in that particular instance, is the exact nature of transcendence, which pertains to being above various forms of materialism; this is known as gunas (ropes) in Hindu philosophy; spiritual ropes that bind the living entity to the world of repeated rebirth. (Bhagavad Gita, 14:22-25) 
Furthering on our analysis, we note that for Jesus to have travelled on the Silk Road at the tender age of thirteen indicates that he was highly intelligent and was very mature for his age hence the family allowed him at his early teens to leave home on such a journey. If we set aside high intellect and maturity, the relevant point to note is that Joseph was sufficiently rich to fund such extensive stay in a foreign land. We can also surmise that in admonishing the rich young man of the above account to "sell whatsoever thou hast, give to the poor... and follow me" Jesus merely asked him to "follow" after his (Jesus') footsteps - severing from the comfort of his wealthy socioeconomic circumstance and seeking the face of God.

\section{Conclusion}

At about 8.30pm on Wednesday, March 13, 2013, Cardinal Jorge Maro Bergoglio of Argentina emerged at the Papal balcony at St. Paul Basilica having been elected Pope by the Conclave in what is considered a record time; that settled hours and days of curiosity and waiting by the catholic faithful and the world over who would succeed Pope Benedict XVI; it also brought fulfillment to thousands who, despite the inclement weather, travelled from far and near to behold the historical moment. And history was made: Cardinal Bergoglio, who was the first runner-up in the Papal race of 2005, became the first Pope from Latin America.

In keeping with the tradition of Roman Catholicism, Cardinal Bergoglio was required to assume a Papal title and he chose Pope Francis I in reverence to St. Francis of Asisi who rejected his well-to-do socioeconomic background, gave away his inherited wealth and moved in with lepers and the poor in the bid to severe from materialism with its legendary capacity to be a "vexation of the spirit," and serve the will of God. In the Marxist parlance, Francis of Asisi committed class suicide; so did Siddhartha Gautama (the messenger of God after whom Buddhism was founded) who disowned his privileged caste in the highly stratified multi-layer Indian society. Born into a royal household with all the appurtenances and accoutrements that go with it, Siddhartha was not only a prince but the Crown Prince of modern-day Nepal; the King in the wing. However, he woke up one morning, rejected that life of wealth and comfort and walked into a life of self-denial in search of the face of the Divine, which he found after painstaking spiritual ordeals and experiences. About six hundred and thirty years after the translation of Siddhartha, Jesus walked away from the comfort of his wealthy circumstance and set off on his mission and ministry of winning souls. 
Rather unfortunately, the clergy erroneously ascribe a poor background to Jesus based on jaundiced assessment of the carpentry trade and lack of knowledge of the pedigree of the Virgin Mary. The carpenter of Jesus' era in Judaea was a noble professional and a lucrative means of livelihood given the state of human development at that epoch. That the profession has taken the back seat in contemporary socioeconomic realities does not change the fact that it was the profession of people of means in that earlier epoch of Judaea.

From Biblical accounts, the impression is created that following the forerunner ministry of John the Baptist in Judaea, Jesus emerged virtually from nowhere, was baptized by John and commenced his ministry. From our analysis, which is informed by materials from the scriptures, extra-biblical literature and other scripture, it is offered that Jesus travelled far and wide and was exposed to privileged education in the East, where the three wise men came from; however, like Siddhartha before him, he walked away from the comfort of his circumstance and embarked on the arduous task of seeking the face of God, which he found at Calvary. It is therefore offered here that Joseph Carpenter was a man of means by the standards obtainable in Judaea of that epoch and that Jesus of Nazareth was, therefore, not born poor; rather, he was born rich.

\section{References}

Bhagavad Gita

Bible, The Holy

Crane, F. (1963). The Lost Books of the Bible and The Forgotten Books of Eden. New York: Penguin Book.

Morgan, T. (2002). Buddha. Novato, CA: New World Library

NA, (2010). Pearls of Wisdom: Collected Wits and Wisdom. Glasgow: Waverly Books Ltd.

Notovich, N. (n.d.). The Unknown Life of Jesus Christ (quoted in) Prophet E.C. (1997). Reincarnation: The Missing Link in Christianity. Corwin Spring, MT.: Summit University Press.

Osai, O.J. (2006). "In His Image and Likeness: Ponderings over Creation and the Divine Essence" in MELINTAS: Journal of Religion and Philosophy. Parahyangan Catholic University, Indonesia. Vol. 22(2) 
Osai, O.J. (2010). "The Musico-spiritual Ministrations of Carlos Santana: An Analysis of his Works." MELINTAS: Journal of Religion and Philosophy. Parahyangan Catholic University, Indonesia. Vol. 26(1), April

Oxford Advanced Learner's Dictionary of Current English, (2009)

Prophet, E.C. (1994). The Lost Teachings of Jesus 3: Keys to SelfTranscendence. Corwin Spring, MT.: Summit University Press.

Prophet, E.C. (1997). Reincarnation: The Missing Link in Christianity. Corwin Springs, MT:Summit University Press

Rowe, A. (2006). The Essence of Jesus. Hertsfordshire: Eagle Editions Ltd.

Schade, J.P. (2006). Encyclopedia of World Religions. New York: Concord Publishing Foreign Media Books

White, G. (1977). Socialization. London: Longman. 